14

23

24

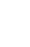

7

8

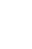

10

1

12

\title{
Predation by Flat Bark Beetles (Coleoptera: Silvanidae and Laemophloeidae) on Coffee Berry Borer
} (Coleoptera: Curculionidae) in Hawaii Coffee

Peter Follett

USDA-ARS-DKI USPBARC

64 Nowelo St.

Hilo, Hawaii 96720

Ph: 808-959-4303, Fax: 808-959-5470

Email: peter.follett@ars.usda.gov 3

Peter A. Follett ${ }^{1}$, Andrea Kawabata ${ }^{2}$, Robert Nelson ${ }^{3}$, Glenn Asmus ${ }^{1}$, Jen Burt ${ }^{2}$, Kally Goschke ${ }^{2}$, Curtis Ewing ${ }^{4}$, Julie Gaertner ${ }^{4}$, Eva Brill ${ }^{1}$ and Scott Geib ${ }^{1}$

6

1 U.S. Department of Agriculture-Agricultural Research Service (USDA-ARS), Daniel K. Inouye U.S. Pacific Basin Agricultural Research Center, Hilo, Hawaii 96720

$\begin{array}{lll}2 & \text { University of Hawaii Cooperative Extension, College of Tropical Agriculture and Human } \\ & 3 & \text { Resources, Kealakekua, HI } 96750 \\ 21 & 4 & \text { Lehu'ula Farms, Kealakekua, Hawaii } 96750\end{array}$


Coffee berry borer (CBB), Hypothenemus hampei (Ferrari) (Coleoptera: Curculionidae) is a serious pest of coffee worldwide and a new invasive pest in Hawaii. Adult flat bark beetles, mainly Leptophloeus sp. (75\%) and Cathartus quadricollis (21\%) (Coleoptera: Laemophloeidae and Silvanidae, respectively), were found inside CBB-infested coffee beans on the tree and molecular marker studies confirmed feeding on $\mathrm{CBB}$. Research was conducted to better understand the ecology of these predators and explore ways to increase their role in suppressing CBB populations in coffee. Laboratory feeding assays demonstrated the capacity for adult and larval flat bark beetles to feed on all CBB life stages. The predators are widely distributed in the coffee growing areas on the island of Hawaii, but feed mainly in dried coffee on the tree rather than in ripening berries where initial crop damage occurs. Berlese funnel extraction of flat bark beetles from dried beans on the tree indicated that predator numbers can be relatively high (up to 23 adult predators per 150 bean sample). C. quadricollis was not susceptible to infection by the fungal biopesticide Beauveria bassiana which is used for field control of CBB in coffee. Leptophloeus sp. and $C$. quadricollis can be raised easily on a diet of cracked corn and cornmeal. Augmentative releases of generalist flat bark beetle predators like Leptophloeus $s p$. and $C$. quadricollis may be a useful component of integrated pest management programs against coffee berry borer and other scolytine pests.

41

Keywords:

predators, coffee, Hypothenemus hampei, Beauveria bassiana, Cathartus quadricollis, square necked grain beetle, Leptophloeus

HIGHLIGHTS:

1. The flat bark beetles Leptophloeus sp. and Cathartus quadricollis feed on coffee berry borer (CBB) in Hawaii coffee

2. Adult and larval predators can feed on all CBB life stages

3. C. quadricollis was not susceptible to infection by the biopesticide Beauveria bassiana used for CBB control in coffee

4. These predators can be reared easily and inexpensively for augmentative releases 
59 GRAPHICAL ABSTRACT:

60

61

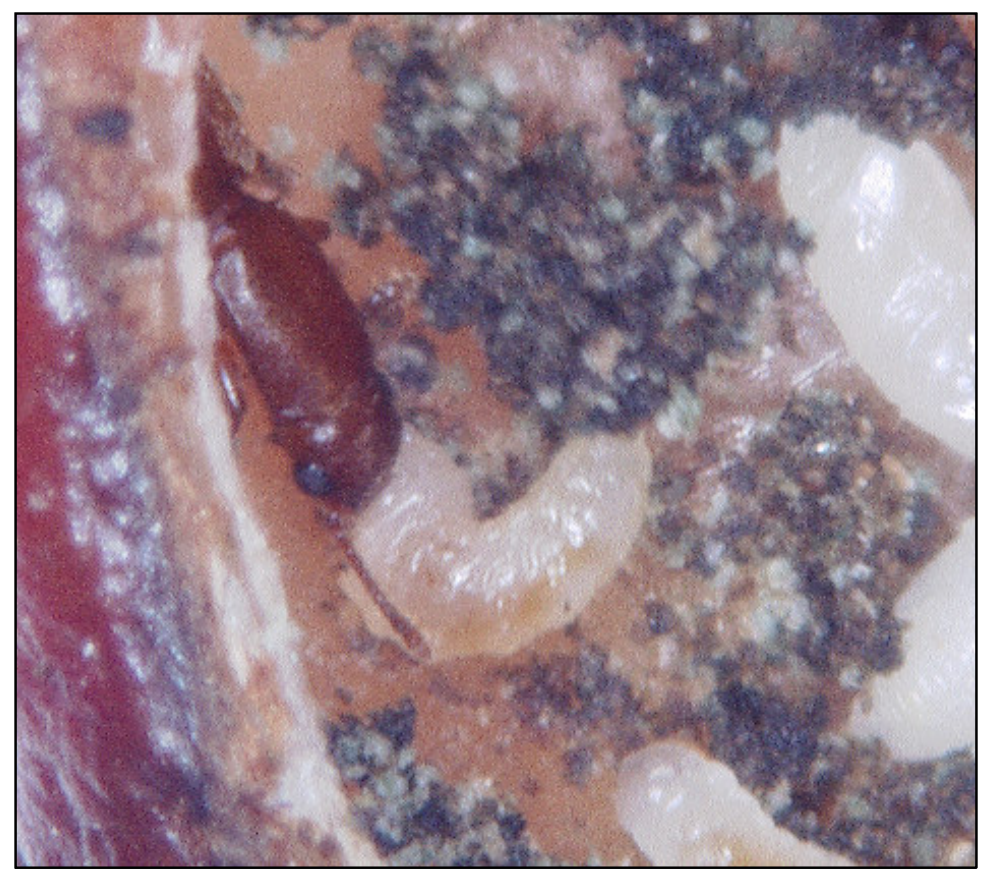

62 Adult Cathartus quadricollis feeding on a coffee berry borer larva inside a coffee berry 63 
The coffee berry borer (CBB), Hypothenemus hampei (Ferrari) (Coleoptera: Curculionidae) is the most important pest of coffee worldwide, with damage exceeding US\$500 million annually (Jaramillo et al., 2006). CBB was first discovered in Hawaii in 2010 on the Kona side of the island of Hawaii where there are about 800 small farms on 1,170 ha, and it has since moved to the island of Oahu (Chapman et al., 2015). CBB is the greatest threat to Hawaii's coffee industry. Current levels of coffee infestation by CBB average $15-20 \%$, which causes yield loss, reduced quality and price, and increased costs (Aristizabal et al., 2016). If left unchecked, CBB can infest $>90 \%$ of coffee berries at harvest.

All CBB life stages develop inside the coffee berry (Aristizabal et al., 2016). Adult females bore into hardened developing green berries and excavate tunnels and galleries in which they lay their eggs. Females may lay $>100$ eggs in a single berry during a three week period. Inside the berry, CBB develops through six life stages: egg, larva (first and second instars), pre-pupa, pupa, and adult, during 1-2 months depending on temperature and hardness of the berry (Baker, 1999). The founding female remains with her progeny and does not leave the berry. Siblings can mate and CBB have a female-biased sex ratio of 10:1. Berry development requires 200-250 days from flowering to harvest, and therefore individual berries can support multiple generations of CBB (Baker et al., 1992). CBB will continue to breed in coffee berries as they ripen, senesce, and dry to the 'raisin' stage. Currently, management of CBB in Hawaii focuses on sampling and monitoring, monthly sprays of the biopesticide Beauveria bassiana, and sanitation (removal of all berries at the end of harvest) (Aristizabal et al., 2016). When harvest is completed, any remaining 'raisin' coffee not stripped from the trees may serve as a source of CBB for the subsequent crop (Vega et al., 2015).

Adult flat bark beetles, mainly the lined flat bark beetle Leptophloeus sp. (Coleoptera: Laemophloeidae) and the silvanid flat bark beetle Cathartus quadricollis (Guerin-Meneville) (Coleoptera: Silvanidae), were found inside CBB-infested coffee berries on trees in Hawaii. Molecular markers were used to verify predation by detecting the presence of CBB DNA in the gut of the flat bark beetles (Sim et al., 2016). In general, the ecology of most flat bark beetles (sensu lato) is poorly understood, but they are known to feed on small insects and mites under bark, and many groups feed on fungi (Thomas, 1993). Some species of flat bark beetles, including species of Leptophloeus, are found only in the galleries of scolytine bark beetles, and a few are stored grain pests, including $C$. quadricollis (the square-necked grain beetle) (Thomas, 1993). C. quadricollis has been collected in Colombia from infested coffee presumably feeding on CBB (Bustillo et al., 2002), Leptophloeus sp. near punctatus has been observed feeding on CBB larvae in Togo and Ivory Coast (Vega et al., 1999), and Leptophloeus sp. and C. quadricollis have been found on macadamia nut in Hawaii where they are likely feeding on another scolytine pest, Hypothenemus obscurus (F.), the tropical nut borer (Jones et al., 1998). Since the lifestyle of CBB is cryptic and its entire life cycle occurs inside the coffee berry, direct study of predators and predation by flat bark beetles is difficult.

Field studies were conducted to determine the geographic and within-plant distribution, abundance, and diversity of flat bark beetles in coffee. Laboratory studies were undertaken to assess flat bark beetle 
102

103

104

105

106

107

108

109

110

111

112

113

114

115

116

117

118

119

120

121

122

123

124

125

126

127

128

129

130

131

132

133

134

135

136

137

preference for feeding on various CBB life stages, and susceptibility of flat bark beetles to infection by the biopesticide Beauveria bassiana used for CBB control.

\section{Materials and methods}

\subsection{Distribution and abundance}

Five farms were selected along an elevation gradient (from 100 to $800 \mathrm{~m}$ ) and infested harvest-ripe coffee berries were sampled weekly to determine if predator numbers increased in response to increasing coffee berry borer infestations as the season progressed. After sampling for seven months and dissection of 2,800 CBB-infested berries, practically no flat bark beetles were collected and it was determined that flat bark beetles do not prefer this crop maturity stage. All studies from that point on focused on raisins (dried berries on the tree), where flat bark beetle predators were more commonly found.

A survey of coffee farms on the island of Hawaii was conducted to determine the distribution of flat bark beetles. CBB-infested coffee raisins were sampled during the coffee harvest period of September to December 2014 in an attempt to determine presence or absence of flat bark beetles. A total of 160 collections were made from 80 coffee farms. Raisins were sampled from coffee trees by walking along rows and systematically sampling raisins from branches with raisins or, when rows were not present by sampling during a zigzag walk through the coffee trees, until a Whirl Pak bag $(118 \mathrm{ml}, 7.6 \times 18.4 \mathrm{~cm}$, Zefon International, Ocala, FL) was filled. A Whirl Pak bag was filled with an average of 150 raisins for every 1 hectare of coffee. Each sample of raisins was placed in a Berlese funnel for $24 \mathrm{~h}$ and flat bark beetles emerging from the funnel were counted and identified.

\subsection{Insect rearing}

The two main species of predator beetles collected from field sampling were an undescribed species of lined flat bark beetle Leptophloeus sp. and the silvanid flat bark beetle Cathartus quadricollis. Laboratory and field studies thus focused on these two species. Adult Leptophloeus sp. and $C$. quadricollis were collected from multiple coffee farms in Captain Cook, Hawaii and reared in the laboratory on a diet of cracked corn and cornmeal $(4: 1)$ in the dark at $24^{\circ} \mathrm{C}\left(+2{ }^{\circ} \mathrm{C}\right)$. Additional beetles were regularly collected from the field and added to the colonies to ensure availability of adults and larvae for laboratory experiments. Predator colonies had overlapping generations, and therefore adult and larval predators used in experiments were of indeterminate age. Coffee berry borer life stages used in experiments were mainly obtained by dissecting infested coffee raisins from the field. Coffee berry borer was also reared in the laboratory using an artificial diet modified from Villacorta and Barrera (1993) and Vega et al. (2011) to supplement field-collected beetles as needed.

\subsection{Feeding preference bioassays}

Laboratory studies were conducted to examine feeding preferences of flat bark beetle adults and larvae for various CBB life stages. In no choice experiments, three flat bark beetles were transferred to a Petri dish ( $100 \times 15 \mathrm{~mm}$ ) that contained 20 prey items on filter paper ( $90 \mathrm{~mm}$ diam. white) moistened with 1 
$\mathrm{ml}$ distilled water and sealed with parafilm. Predators were the adult or late larval stage of Leptophloeus sp. or C. quadricollis and prey were CBB eggs, second instar larvae, pupae or adults. After $24 \mathrm{~h}$ in the dark at $24^{\circ} \mathrm{C}\left(+2{ }^{\circ} \mathrm{C}\right)$, predators were removed and any remaining CBB prey items were assessed and counted. Eggs and larvae were typically entirely eaten by the predators, whereas pupae were only partially consumed, and adults were maimed (e.g. missing legs). If the prey item was missing (egg, larva) or dead with noticeable wounds (pupa, adult) it was recorded as 'consumed'. In choice experiments, experimental conditions were identical except three predators were placed with 40 prey items, ten each of each CBB life stage (eggs, larvae, pupae and adults). Data on numbers consumed were subjected to analysis of variance and means separations were performed using a post-hoc Tukey's test (SAS, 2014).

\subsection{Coffee berry maturity effect}

A study was conducted to quantify the effect of coffee berry maturity stage on infestation level by flat bark beetles. Coffee trees have indeterminate flowering in Hawaii and therefore all maturity stages of berries can occur on the same branch. One hundred CBB-infested ripe, overripe and raisin stage coffee berries were collected from each of three trees on five farms. Each maturity stage by tree by farm sample was placed in a separate a Berlese funnel and all flat bark beetles emerging from the funnels at $24 \mathrm{~h}$ were counted and identified. Data for numbers of flat bark beetles were log transformed and subjected to analysis of variance and means separations were performed using a Tukey's test.

\subsection{Tree versus ground berries}

Flat bark beetles are difficult to find in CBB-infested coffee berries on the ground. A study was conducted to quantify the effect of coffee berry location (tree versus ground) on flat bark beetle occurrence. Seventeen samples were collected from nine farms by collecting CBB-infested raisins both in the tree and recently fallen on the ground during a random walk. Multiple samples were taken from several large farms by sampling different areas of the farm. Sample sizes ranged from 50 to 200 raisins per sample with a mean (+SE) sample size of $123 \pm 7.4$. Each sample was placed in a separate Berlese funnel and all flat bark beetles emerging from the funnels at $24 \mathrm{~h}$ were counted and identified. Data for numbers of flat bark beetles were log transformed and subjected to analysis of variance.

\subsection{Beauveria bassiana dip bioassay}

A laboratory study was conducted to determine relative levels of susceptibility between CBB and Cathartus quadricollis to infection by Beauveria bassiana formulated in BotaniGard ES (11.3\% Al, Laverlam International Corp., Butte, MT), which is used for field control of CBB in Hawaii. C. quadricollis was used as a proxy for flat bark beetles in general. Diet-reared $C$. quadricollis and CBB were used to minimize previous exposure to $B$. bassiana. A dip bioassay was performed using a dilution series of the commercial product. Treatments were a 0.5X, 1.0X 2.0X of the field rate of BotaniGard (field rate 0.25 liters/100 liters) plus a surfactant (Widespread Max, field rate 0.04 liters/100 liters). Specifically, the 2.0X field rate solution contained $2.5 \mathrm{ml}$ BotaniGard plus $0.39 \mathrm{ml}$ Widespread Max in a $1 \mathrm{~L}$ final mixture. For each treatment, 40 adult CBB or $C$. quadricollis were transferred to a $29.6 \mathrm{ml}$ plastic cup (Dart conex complements portion container, Mason, $\mathrm{Ml}$ ), a $10 \mathrm{ml}$ BotaniGard suspension was added to the cup, and then the cup was capped and inverted repeatedly for three seconds. After dipping, the contents of the 
cup were poured onto sterile paper towels and treated beetles were transferred with a paint brush to Petri dishes $(100 \times 15 \mathrm{~mm}$ ) containing filter paper (90 mm diam. white) moistened with $1 \mathrm{ml}$ distilled water and a small amount of food (20 grains of cracked corn for C. quadricollis; $5 \mathrm{ml}$ artificial diet for CBB) and sealed with parafilm. Individual Petri dishes with treated beetles were placed inside plastic Ziploc bags to prevent escapes. Control insects for both species were dipped in sterile distilled water only and processed and held similarly. The dip test was replicated four times at each dose for each species. At 10 days, all beetles were scored as alive, dead or moribund by prodding with a fine tipped paint brush, and dead or moribund beetles were inspected for $B$. bassiana colony growth under a stereomicroscope. Data for percentage mortality and B. bassiana infection were subjected to analysis of variance and means separations were performed using a Tukey's test.

\section{Results}

\subsection{Distribution and abundance}

Leptophloeus sp. and Cathartus quadricollis were the most common predators found feeding inside CBBinfested coffee berries collected from coffee trees in our survey, accounting for $75 \%$ and $21 \%$ of captures respectively (Table 1). Adult predators, but not larvae, were collected in the survey. Several other species of potential predators were also encountered albeit rarely (Table 1). Since the only prey item in coffee berries in Hawaii is CBB, it is assumed that these other beetles may have been predating on $\mathrm{CBB}$, although this was not determined by DNA analysis of gut contents. Corticeus pratermissus is listed as a bark beetle predator in Wegensteiner et al. (2015). Cryptamorpha desjardinsii is reportedly predaceous in the larval stage (Thomas, 1993). Silvanus bidentatus is reported as a predator of Tomicus bark beetles (Lieutier et al., 2015). Aneorps sp. is a monotomid and many species within this family are found in the galleries of scolytine bark beetle and are thought to be predaceous (Sen Gupta, 1988; Wegensteiner et al., 2015). Xylolestes laevior is a laemophloeid and a number of species in this family occur in the galleries of scolytine bark beetles as well (Thomas, 1993).

Leptophloeus sp. and C. quadricollis were found at all elevations (100-800 m) and in all the coffee farming areas sampled (Fig. 1). Repeated sampling resulted in finding one or the other or both of these predators on all coffee farms sampled. The numbers of adult flat bark beetles collected from a sample of 150 dried berries ranged from 0 to a high of 23 (Fig. 2).

\subsection{Feeding preference bioassays}

In no choice laboratory feeding studies, where predators were presented with one CBB life stage at a time (20 prey items per 3 predators), percent prey consumption was significant for the effect of predator species $\left(F_{1,1}=19.4, P<0.0001\right)$, the predator species by predator life stage interaction $\left(F_{1,1}=\right.$ $17.5, P<0.0001), C B B$ prey stage $\left(F_{13,3}=36.6, P<0.0001\right)$, and the predator stage by CBB prey life stage interaction $\left(F_{3,3}=3.4, P=0.02\right)$. Overall, $C$. quadricollis ate significantly more $C B B$ than Leptophloeus $\mathrm{sp}$. (Figs. 3, 4). C. quadricollis adults ate significantly more $C B B$ than $C$. quadricollis larvae $\left(F_{1,1}=13.0, P<\right.$ 0.001). Adult $C$. quadricollis ate significantly more CBB eggs (77.5\%), larvae $(55.0 \%)$ and pupae (53.0\%) than adults (15.5\%) $(\mathrm{P}<0.05)$; and larval $C$. quadricollis ate more CBB eggs $(63.0 \%)$ than larvae $(31.5 \%)$, pupae $(19.0 \%)$ and adults $(6.0 \%)(P<0.05)$. Although predator feeding on CBB adults in no choice tests 
generally involved eating the legs, in one instance a $C$. quadricollis larvae had eaten a significant portion of the body of a teneral CBB adult. Unlike $C$. quadricollis, Leptophloeus sp. larvae ate more $\mathrm{CBB}$ than Leptophloeus sp. adults $\left(\mathrm{F}_{1,1}=5.4, \mathrm{P}<0.001\right)$ (Fig. 4). Larval Leptophloeus sp. ate significantly more CBB eggs $(74.0 \%)$ than larvae (22.5\%), pupae (19.0\%) and adults $(0.9 \%)(P>0.05)$; and adult Leptophloeus sp. ate significantly more CBB eggs $(32.5 \%)$ and larvae $(29.0 \%)$ than pupae $(8.5 \%)$ or adults $(0 \%)(P<0.05)$.

In the choice tests, where predators were presented all CBB life stages simultaneously, percent prey consumption was significant for the effect of predator species $\left(F_{1,1}=15.6, P=0.0002\right)$, the predator species by predator life stage interaction $\left(F_{1,1}=4.3, P=0.04\right)$, CBB prey stage $\left(F_{3,3}=35.6, P<0.0001\right)$, and the predator species by $C B B$ prey life stage interaction $\left(F_{13,3}=5.5, P=0.002\right)$. Overall, $C$. quadricollis ate significantly more CBB than Leptophloeus sp. (36.3\% versus $18.8 \%$ of prey items) (Figs. 5,6$)$. C. quadricollis adults and larvae ate equal numbers of $C B B$ life stages $\left(F_{1,1}=3.4, P=0.07\right)$. Adult $C$. quadricollis ate significantly more CBB eggs (78.3\%) than larvae (38.3\%), and significantly more larvae than pupae $(6.7 \%)$ and adults $(0.0 \%)(P<0.05)$. Larval $C$. quadricollis ate significantly more $\mathrm{CBB}$ eggs (75.0\%) and larvae $(71.7 \%)$, than pupae $(20.0 \%)$ and adults $(0 \%)(P<0.05)$. Leptophloeus sp. adults and larvae ate equal numbers of $\mathrm{CBB}\left(\mathrm{F}_{1,1}=1.4, \mathrm{P}=0.24\right)$. Adult Leptophloeus $\mathrm{sp}$. ate significantly more $\mathrm{CBB}$ eggs $(48.3 \%)$ than larvae $(16.7 \%)$ and adults $(0 \%)(P<0.05)$, and an intermediate number of pupae (25.0\%). Larval Leptophloeus sp. ate significantly greater numbers of CBB eggs $(36.7 \%)$ than adults $(0 \%)$ $(P<0.05)$, and an intermediate number of larvae $(20 \%)$ and pupae $(8.3 \%)$.

The often higher consumption rates of eggs by predators may be due to the smaller size of eggs compared to the other life stages. Coffee berry borer eggs weighed on average $0.047 \mathrm{mg}$, whereas the larvae, pupae and adults used in the tests weighed on average $0.46,0.49$ and $0.39 \mathrm{mg}$, respectively, or approximately 10 times more. Thus, handling time for eggs may have been less than the other larger life stages. CBB adults suffered the lowest mortality probably due to their heavier sclerotization and higher mobility than the other stages. C. quadricollis generally ate more CBB than Leptophloeus sp., probably due to its larger size. Adult $C$. quadricollis weighed on average $0.70 \mathrm{mg}$, more than twice the average weight of Leptophloeus sp. adults which was $0.33 \mathrm{mg}$. In choice tests, C. quadricollis adults ate $78.3 \%$ of CBB eggs and $38.3 \%$ of larvae compared with $48.3 \%$ and $16.7 \%$ respectively for Leptophloeus sp.

\subsection{Maturity stage and location}

The effect of coffee berry maturity stage on numbers of predators in CBB-infested coffee berries was significant $\left(F_{2,41}=7.4, P<0.002\right)$. Coffee raisins were the most preferred habitat for Leptophloeus sp. and $C$. quadricollis adults, followed by overripe berries; predators were rare in ripe berries (Fig. 7). The location of coffee raisins was also important; Leptophloeus sp. and C. quadricollis adults were more commonly found in raisins on the tree than in newly dropped raisins on the ground $\left(t_{1,33}=4.2, P<0.05\right)$ (Fig. 8).

\subsection{Beauveria bassiana dip bioassay}

In the Beauveria dip bioassay with $\mathrm{CBB}$ and $C$. quadricollis, percentage mortality was not significant for the effect of species $\left(F_{1,3}=0.001, P<0.001\right)$, but was significant for the effect of concentration $\left(F_{3,31}=\right.$ $3.4, \mathrm{P}<0.04)$ and the species by concentration interaction $\left(\mathrm{F}_{6,31}=3.1, \mathrm{P}<0.05\right)$. Percentage infection by 
B. bassiana was significant for the effect of species $\left(\mathrm{F}_{1.3}=22.9, \mathrm{P}<0.001\right)$, and marginally not significant for the effect of concentration $\left(F_{3,31}=2.7, P<0.06\right)$ and the species by concentration interaction $\left(F_{6,31}=\right.$ 2.7, $\mathrm{P}<0.06$ ) (Table 2). Percentage mortality in CBB increased as the BotaniGard treatment concentration increased from $0.5 \mathrm{X}$ to $2.0 \mathrm{X}$ the field rate, and $B$. bassiana infection was visible in $55-75 \%$ of dead beetles in the BotaniGard treatments. Percentage mortality was variable for $C$. quadricollis, but no B. bassiana infection was observed in dead beetles in the BotaniGard treatments (Table 2).

\section{Discussion}

Our study showed that Leptophloeus sp. and Cathartus quadricollis are the most common predators inside CBB-infested coffee berries in coffee trees. Laboratory feeding assays demonstrated the capacity for adults and larvae of both species to feed on all life stages of CBB. Molecular marker studies confirmed that $C$. quadricollis and Leptophloeus sp. adults collected from dried berries on trees in the field were feeding on CBB (Sim et al., 2016). These predators are widely distributed in the coffee growing areas on the island of Hawaii, but feed mainly in dried coffee on the tree rather than in ripening berries where crop damage occurs. Predator numbers can be quite high, with up to 23 adult predators collected from a sample of 150 dried berries. The predators do not appear to be susceptible to the fungal biopesticide $B$. bassiana which is widely used for field control of CBB in coffee. Unlike other coffee growing areas around the world, flat bark beetles are the most common natural enemies of CBB in Hawaii.

Primarily adult flat bark beetles have been collected in coffee raisins, with relatively few collections of larvae and no collections of pupae. This suggests that flat bark beetle reproduction in CBB-infested coffee berries may be limited. The search for immature life stages of flat bark beetles in the field is ongoing. Recent studies have shown that all life stages of $C$. quadricollis and Leptophloeus sp. can be found in macadamia nut (Macadamia integrifolia), and in the seed pods of Leucaena leucocephala and several other leguminous trees, which are all common plants in the coffee landscape in Hawaii (Brill and Follett, unpublished data). These host plants harbor a variety of insects, including other scolytine pests, such as tropical nut borer and black twig borer, Xylosandrus compactus (Eichoff). Additional molecular markers are being developed to study patterns of flat bark beetle predation on other scolytine bark beetles in the coffee landscape. The life history of $C$. quadricollis and Leptophloeus sp. in Hawaii may be linked to these alternate hosts where development and reproduction occurs. The absence or shortage of reproductive host plants for these predators may explain why they are not more common in other coffee growing regions. Movement patterns from these alternate hosts into coffee should be studied to determine if there are ways to enhance immigration.

Natural enemies of CBB found in other coffee growing regions do not occur or are not common in Hawaii. Parasitoids used in augmentative release programs in other countries such as Phymasticus coffea and Cephalonomia stephanoderis are not present in Hawaii, and the predatory thrips Karnyothrips flavipes is present but is rarely seen in coffee. Classical biological control using parasitoids should be explored but may be hampered in practicality by the large number of native Xyleborus bark beetles in Hawaii that must be considered for non-target effects during host specificity testing (Aristizabal et al., 2016). 
291 The results of our studies with flat bark beetle predators suggest their possible use in augmentative

292 biological control. These predators are mainly attacking CBB in dried coffee left on the tree after

293 harvest. Therefore, their role in CBB management will be to suppress population growth in unharvested

294 coffee between seasons and in abandoned coffee. Cathartus quadricollis and Leptophloeus sp. can be

295 raised inexpensively on a diet of cracked corn and cornmeal. Hawaii coffee growers were shown how to

296 raise flat bark beetles on this diet and many farmers are now periodically releasing home-grown

297 predatory beetles on their farms to augment existing populations. An aggregation pheromone has been

298 identified for C. quadricollis (Pierce et al., 1988) and we are exploring ways to use pheromone and

299 kairomone lures to draw greater numbers of the predators into coffee fields. A pheromone for the more

300 common predator Leptophloeus sp. has not been identified yet. Augmentative release of predatory flat

301 bark beetles that are easily reared in large numbers like Leptophloeus and C. quadricollis could be a

302 useful component of an integrated pest management program for other scolytine pests as well.

\section{Acknowledgements}

306 We are grateful to Raymond Carruthers (University of Hawaii Cooperative Extension) and Nicholas 307 Manoukis (USDA-ARS, Hilo, HI) and two anonymous reviewers for their helpful comments on an early 308 draft of the manuscript. This research was supported partly by extramural grants from the Hawaii 309 Department of Agriculture and the U.S Department of Agriculture, Agricultural Research Service.

\section{Video}

312 A video of a C. quadricollis adult chewing on a CBB larva in a CBB-infested coffee bean collected from the 313 field can be viewed here: http://moana.dnsalias.org/ follett/Cathartus chewing on CBB larva.avi 
Allotey, J., and Morris, J.G., 1993. Biology of Cathartus quadricollis Guerin-Meneville (Coleoptera: Silvanidae) on some selected media. Insect Science and Its Application 14, 61-68.

318

319

320

321

322

323

324

325

326

327

328

329

330

331

332

333

334

335

336

337

338

339

340

341

342

343

344

345

346

347

348

349

350

351

Aristizabal, L.T., Bustillo, A.E., and Arthurs, S.P. 2016. Integrated pest management of coffee berry borer: strategies from Latin America that could be useful for coffee farmers in Hawaii. Insects 7, 6; doi:10.3390/insects7010006, 24 pp.

Baker, P., 1999. The coffee berry borer in Colombia. DFID-Cenicafe CABI Bioscience IPM for Coffee Project (CNTR 93/1536A); Cenicafe: Chinchina, Colombia, p. 154.

Baker, P., Barrera, J.F., Rivas, A. 1992. Life-history studies of the coffee berry borer (Hypothenemus hampei, Scolytidae) on coffee trees in southern Mexico. J. Appl. Entomol. 29: 656-662.

Bustillo, A.E., Cardenas, R., Posada, F.J., 2002. Natural enemies and competitors of Hypothenemus hampei (Ferrari) (Coleoptera: Scolytidae) in Colombia. Neotropical Entomology 31 (4), 635-639.

Chapman, E.G., Messing, R.M., Harwood, J.D., 2015. Determining the origin of the coffee berry borer invasion of Hawaii. Annal. Entomol. Soc. Amer. 108 (4): 585-592.

Jaramillo, J., Borgemeister, C., and Baker ,P., 2006. Coffee berry borer Hypothenemus hampei (Coleoptera: Curculionidae): searching for sustainable control strategies. Bull. Entomol. Res. 96, 223233.

Jones, V. P., Finson, N. N., Richardson, M. S., 1998. Tropical nut borer natural enemies and koa seedworm management update. In: Proc. $38^{\text {th }}$ Annual Conference of the Hawaiian Macadamia Nut Assoc., pp. 5-9.

Kovach, J., Gorsuch, C.S., 1985. Survey of ambrosia beetle species infesting South Carolina peach orchards and a taxonomic key for the most common species. J. Agric. Entomol. 2(3), 238-247.

Lieutier, F., Langstrom, B., Faccoli, M., 2015. The genus Tomicus, In: Vega, F.E., Hofstetter R.W. (eds.), Bark Beetles: Biology and Ecology of Native and Invasive Species. Academic Press, New York, pp. 371-426.

Neto, A. P., Pimentel, M.A.G., Faroni, L.R.D’A., de Sousa, A. H.. 1999. Population growth and grain loss of Cathartus quadricollis (Guerin-Meneville) (Coleoptera: Silvanidae) in different stored grains. pp. 463468 , In $9^{\text {th }}$ International Working Conference on Stored Porduct Protection.

Pierce, H. D., Pierce, A.M., Johnson, B. D., Oelschlager, A. C., Borden, J. H., 1988. Aggregation pheromone of square-necked grain beetle, Cathartus quadricollis (Guer.). J. Chem Ecol. 14, 21692184. 
Posada, F., Vega, F. E., 2005. A new method to evaluate the biocontrol potential of single spore isolates of fungal entomopathogens. J. Insect Sci. 5, 37.

SAS Institute. 2014. JMP user's guide. SAS Institute, Cary, North Carolina, USA.

Sen Gupta, T., 1988. Review of the genera of the Rhizophagidae (Clavicornia: Coleoptera) of the world. Memoirs of the Zoological Survey of India, v. 17, 58 pp.

Sim, S., Yoneishi, N.M., Brill, E., Geib, S.M., Follett, P.A., 2016. Molecular markers detect cryptic predation on coffee berry borer (Coleoptera: Curculionidae) by silvanid and laemophloeid flat bark beetles (Coleoptera: Silvanidae, Laemophloeidae) in coffee beans. J. Econ. Entomol. 109: 100-105.

Thomas, M., 1993. The Flat Bark Beetles of Florida (Coleoptera: Silvanidae, Passandridae, Laemophloeidae), v. 15, In: Arthropods of Florida and Neighboring Land Areas, Florida Dept. Agric. Consum. Serv. Contribution No. 789, 101 pp.

United States Department of Agriculture (USDA), National Agriculture Statistics Service (NASS), 2016. Hawaii coffee marketings - preliminary season estimates. February 17, 2016.

Vega, F.E., Mercadier, G., Damon, A., Kirk, A., 1999. Natural enemies of the coffee berry borer, Hypothenemus hampei (Ferrari) (Coleoptera: Scolytidae) in Togo and Ivory Coast, and additional entomofauna associated with coffee beans. Afr. Entomol. 7, 243-248.

Vega, F. E., F. Infante, A. Castillo, and J. Jaramillo. 2009. The coffee berry borer, Hypothenemus hampei (Ferrari) (Coleoptera: Curculionidae): a short review, with recent findings and future research directions. Terr. Arthropod Rev. 2, 129-147.

Vega, F. E., M Kramer, and J. Jaramillo. 2011. Increasing coffee berry borer (Hypothenemus hampei; Coleoptera: Curculionidae: Scolytinae) female density in artificial diet increases fecundity. J. Econ. Entomol. 104, 87-93.

Vega, F.E., Infante, F., Johnson, A.J., 2015. The genus Hypothenemus, with emphasis on $H$. hampei, the coffee berry borer, In: Vega, F.E., Hofstetter R.W. (eds.), Bark Beetles: Biology and Ecology of Native and Invasive Species. Academic Press, New York, pp. 427-494.

Villacorta, A. and J. F. Barrera. 1993. Nova dieta meridica para criacao de Hypothenemus hampei (Ferrari, 1867). An. Soc. Entomol. Bras. 22, 405-409.

Wegensteiner, R., Werelinger, B., Herrman, M., 2015. Natural enemies of bark beetles: predators, parasitoids, pathogens, and nematodes, In: Vega, F.E., Hofstetter R.W. (eds.), Bark Beetles: Biology and Ecology of Native and Invasive Species. Academic Press, New York, pp. 247-304. 
385 Table 1

386 Predatory beetles collected during three months using Berlese funnels from samples of CBB-infested 387 dried coffee beans ('raisins') picked from the coffee tree.

388

389

390

Family

No.

Percentage

Percentage

captured

captures $^{\mathrm{a}}$

samples $^{b}$

391

392

Leptophloeus sp.

Laemophloeidae

435

76.6

59.0

393 Cathartus quadricollis

Silvanidae

118

20.8

24.6

394 Corticeus praetermissus

Tenebrionidae

1

0.2

0.7

395 Cryptamorpha desjardinsii

Silvanidae

7

1.2

3.7

396 Aneurops sp.

Monotomidae

5

0.9

3.7

$397 \quad$ Xylolestes laevior

Laemophloeidae

1

0.2

0.7

398 Silvanus bidentatus

Silvanidae

1

0.2

0.7

399

400 a Percentage of overall beetle captures (no. captured/total no. captured)

401 b Percentage of samples containing each species; $20 \%$ of samples contained both Leptophloeus 402 sp. and $C$. quadricollis

403 


\section{Table 2}

Susceptibility of coffee berry borer and Cathartus quadricollis to formulated Beauveria bassiana (BotaniGard ES) using a dip bioassay (mean + $\mathrm{SE})$.

\begin{tabular}{|c|c|c|c|c|c|c|}
\hline \multirow[t]{2}{*}{ Field rate } & \multirow[t]{2}{*}{ No. tested } & \multicolumn{2}{|c|}{ Coffee berry borer } & \multirow[t]{2}{*}{ No. tested } & \multicolumn{2}{|c|}{ Cathartus quadricollis } \\
\hline & & Mortality (\%) & $\begin{array}{l}\text { B. bassiana } \\
\text { infection (\%) }\end{array}$ & & Mortality (\%) & $\begin{array}{l}\text { B. bassiana } \\
\text { infection (\%) }\end{array}$ \\
\hline Control & 154 & $5.8(2.2) a$ & $5.8(2.2) a$ & 149 & $5.3(2.6) a$ & 0 \\
\hline 0.5 & 151 & $28.5(6.1) a b$ & $15.7(3.1) a$ & 158 & $32.5(15.3) \mathrm{a}$ & 0 \\
\hline 1.0 & 157 & 32.0 (22.9)ab & $23.8(16.5) a$ & 156 & $10.9(8.4) a$ & 0 \\
\hline 2.0 & 154 & $68.0(9.5) b$ & $41.5(6.6) a$ & 151 & $11.2(6.0) a$ & 0 \\
\hline
\end{tabular}

a Means within a column followed by the same letter are not significantly different by a Tukey's test $(P>0.05)$ 
Fig. 1. Coffee farms on the island of Hawaii surveyed for flat bark beetle predators.

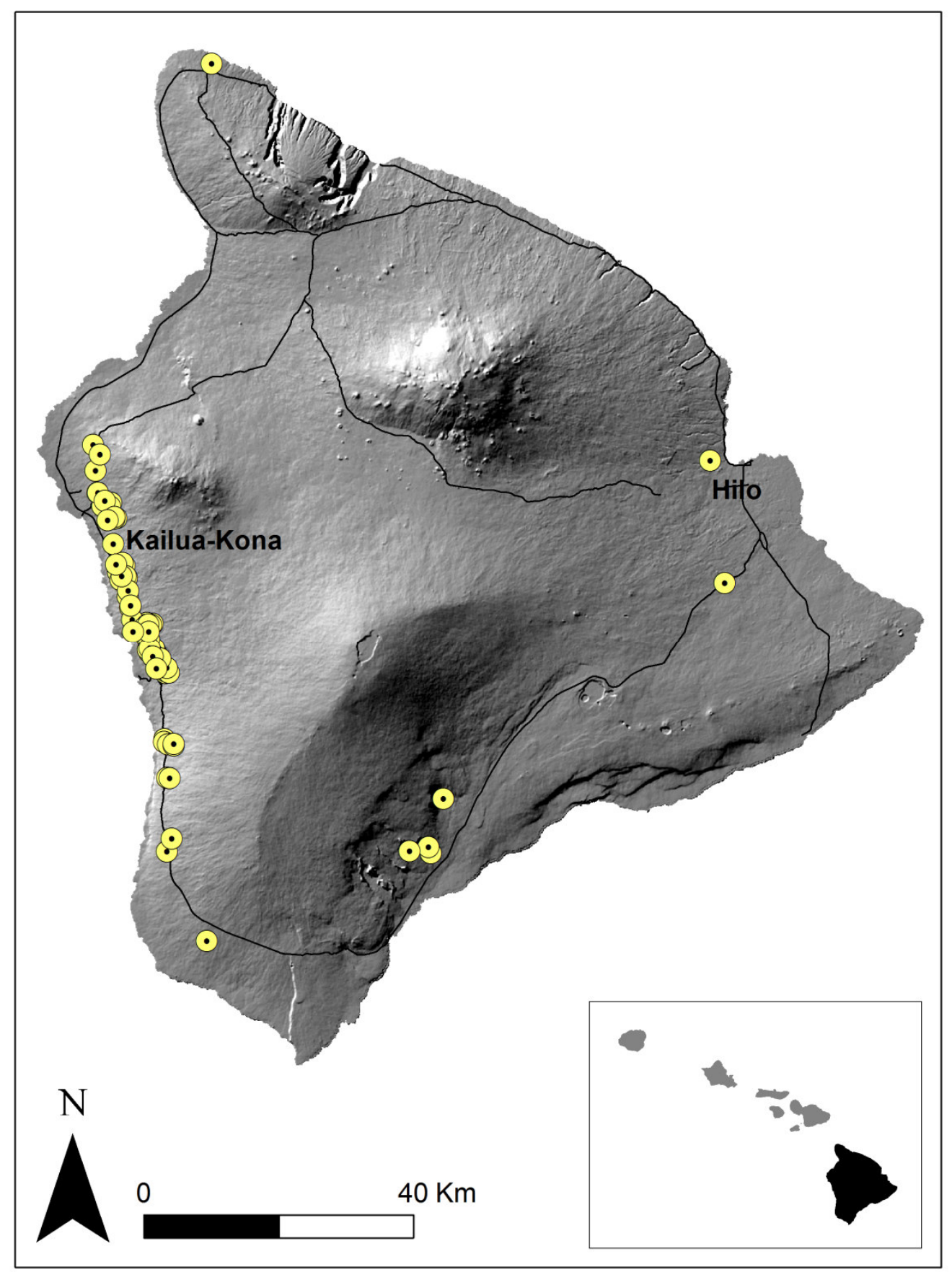




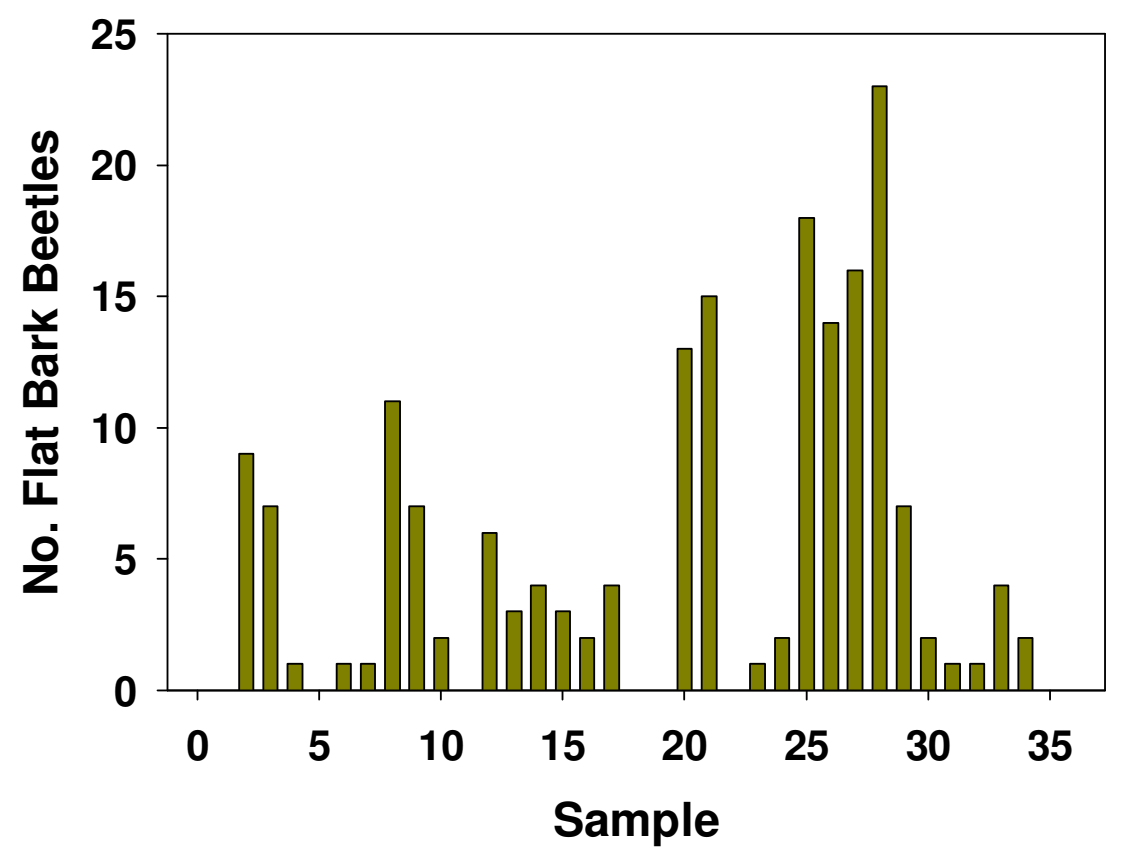

Fig. 2. Total number of flat bark beetles collected per 150 raisin sample from each of 35 coffee farms. 


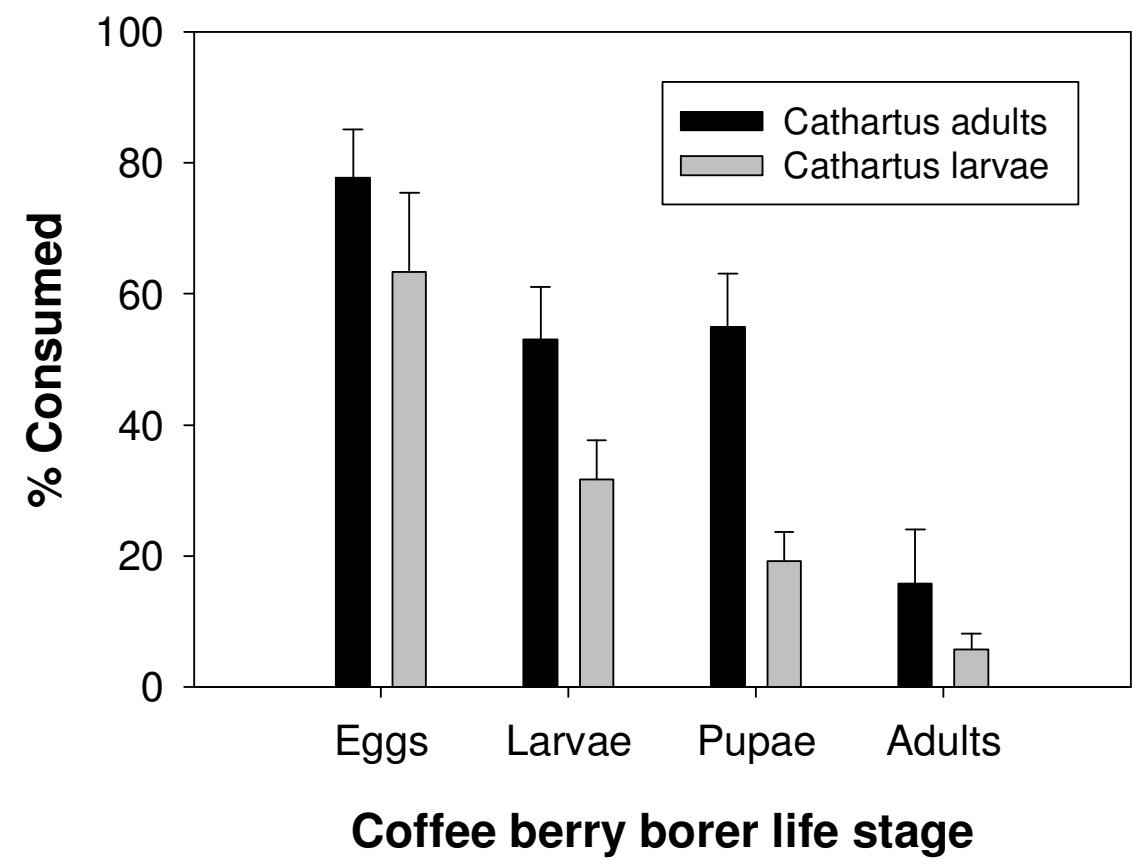

Fig. 3. No choice bioassay: average consumption (mean $\% \pm \mathrm{SE}$ ) by Cathartus quadricollis adults and larvae of coffee berry borer life stages when presented independently. 


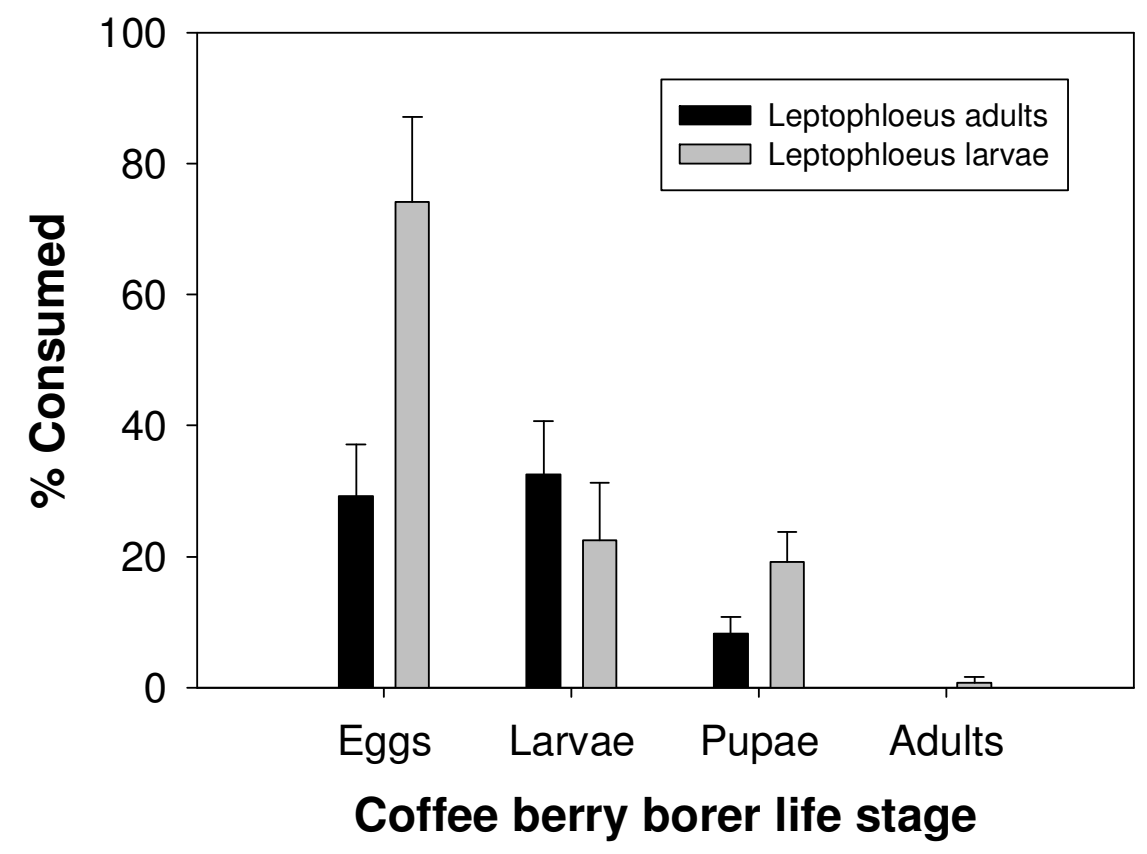

Fig. 4. No choice bioassay: average consumption (mean $\% \pm \mathrm{SE}$ ) by Leptophloeus sp. adults and larvae of coffee berry borer life stages when presented independently. 


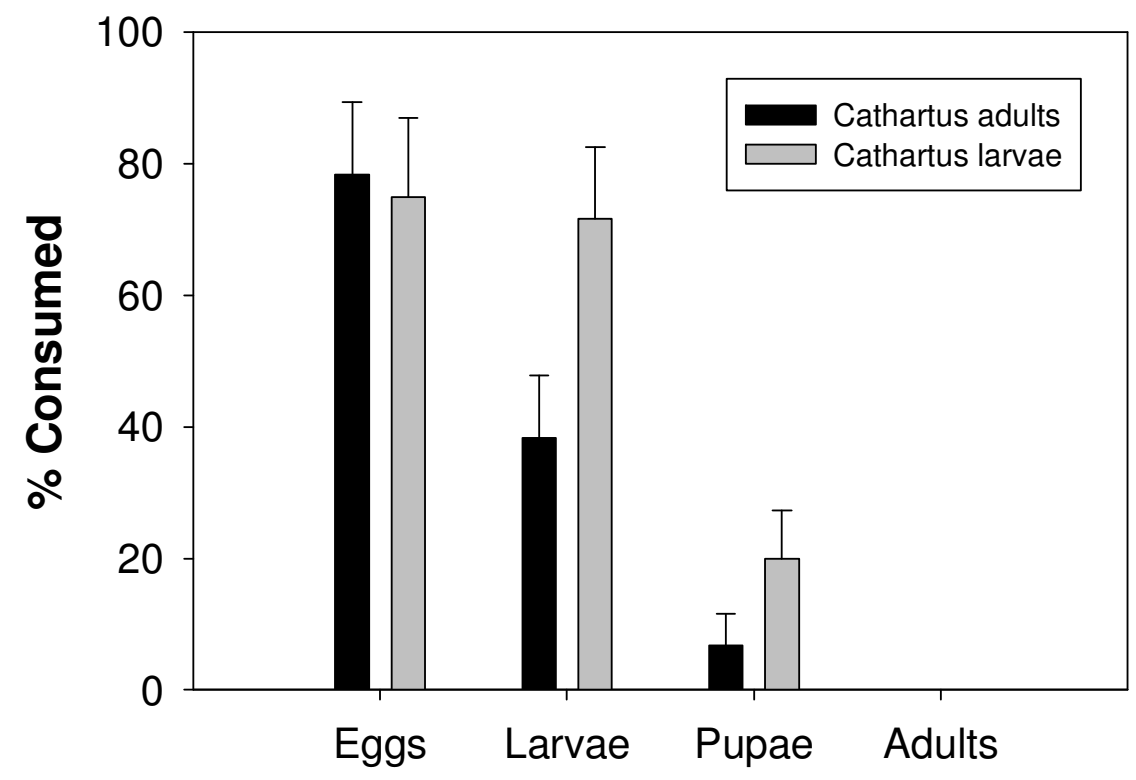

Fig. 5. Choice bioassay: average consumption (mean $\% \pm \mathrm{SE}$ ) by Cathartus quadricollis adults and larvae of coffee berry borer life stages when presented simultaneously. 


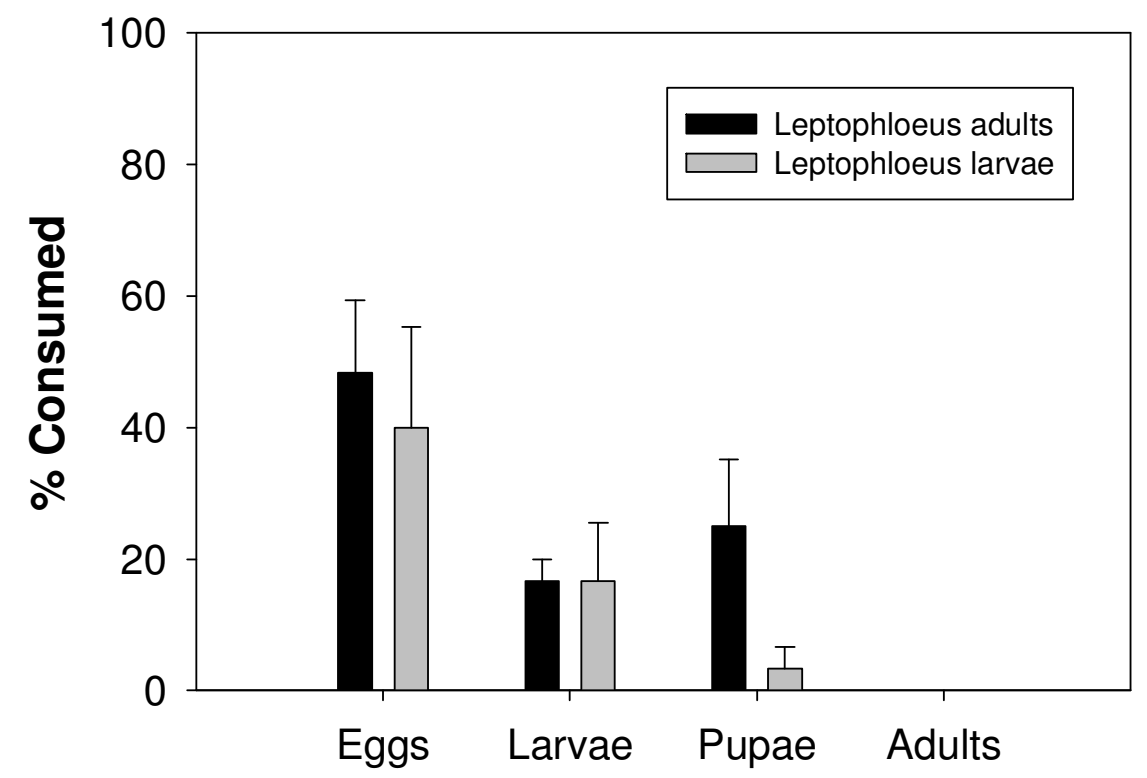

Fig. 6. Choice bioassay: average consumption (mean $\% \pm \mathrm{SE}$ ) by Leptophloeus sp. adults and larvae of coffee berry borer life stages when presented simultaneously. 


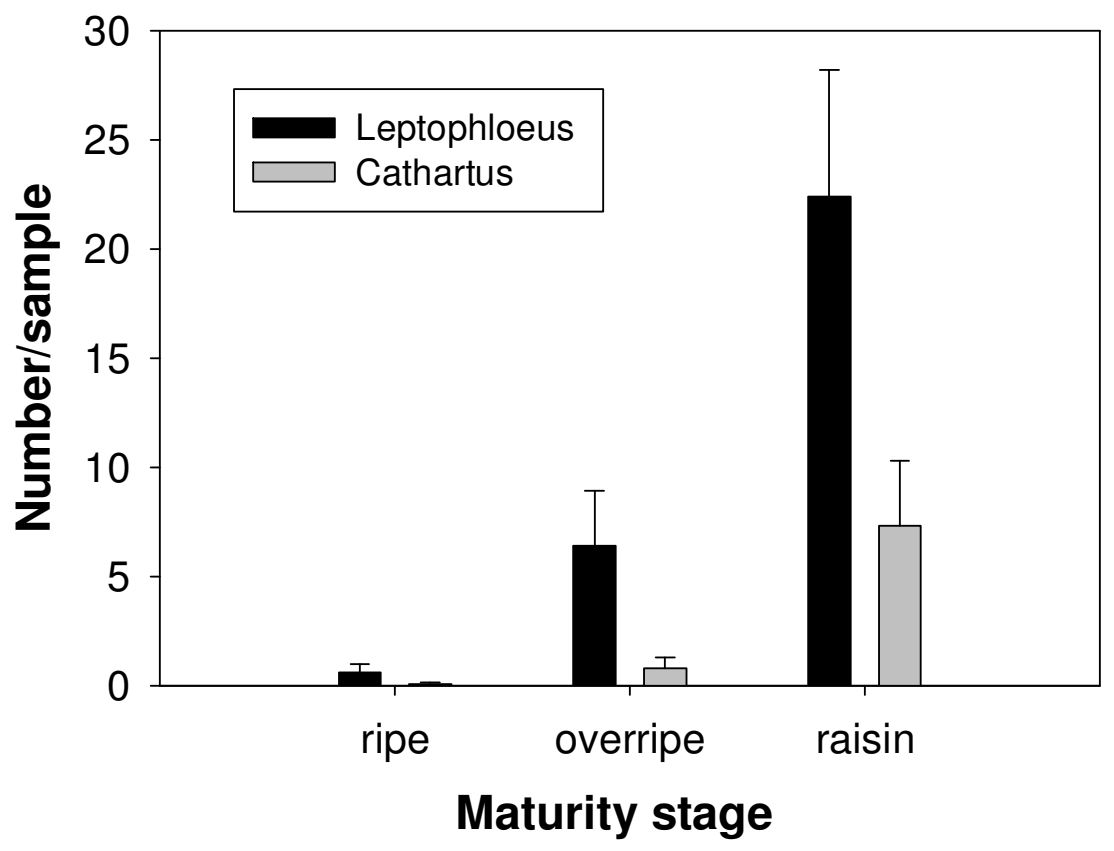

Fig. 7. Mean number $( \pm S E)$ of flat bark beetles from samples of berries of different maturity stage (100 berries/sample) 


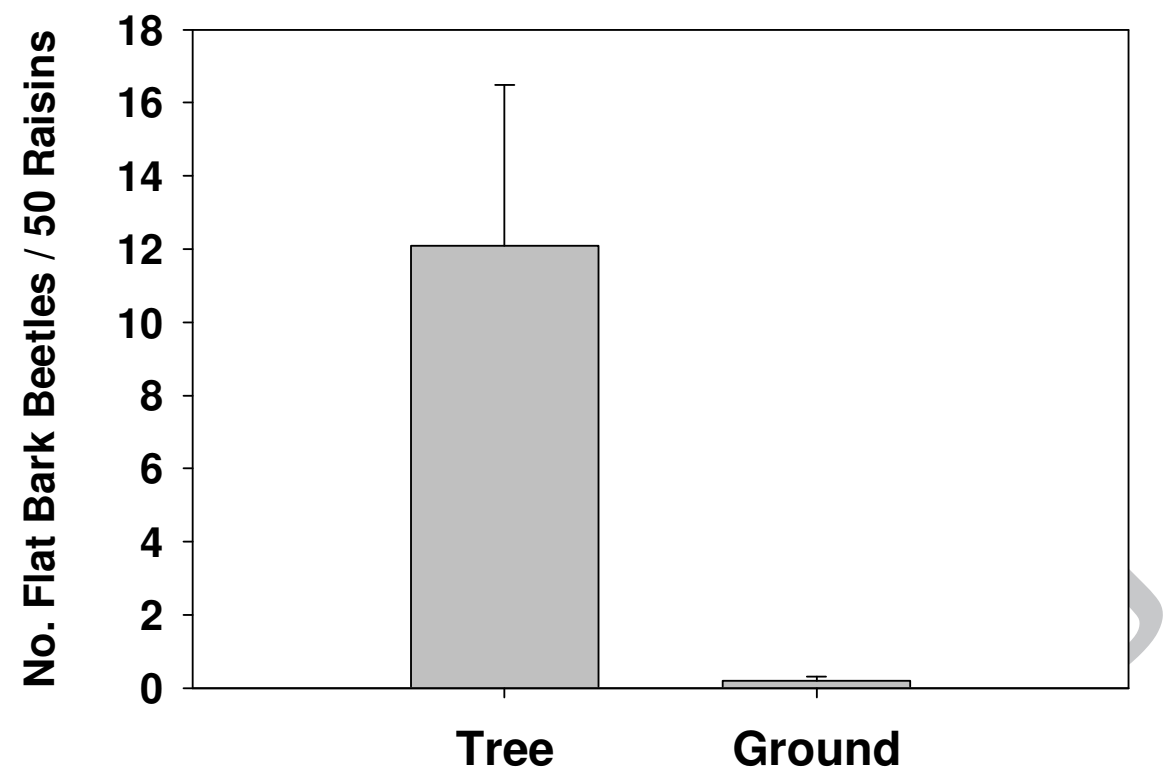

Fig. 8. Mean ( $\pm \mathrm{SE})$ number of flat bark beetle predators (Leptophloeus sp. and C. quadricollis) per 50 coffee berries sampled from the ground or from the tree (No. farms $=15$ ). 